\title{
Systematic review and evolution of the early Cytheruridae (Ostracoda)
}

\author{
ROBIN WHATLEY ${ }^{1} \&$ IAN BOOMER ${ }^{2}$ \\ 'Micropalaeontology Research Group, University of Wales, Aberystwyth SY23 3DB, UK. \\ ${ }^{2}$ Department of Geography, University of Newcastle, Newcastle NE1 7RU, UK.
}

\begin{abstract}
A review of the literature on the taxonomy of Triassic and Early Jurassic cytheracean Ostracoda reveals that the validity of many genera is questionable. A number of studies of the Triassic microfaunas from eastern European sequences have, in particular, obscured the true generic and suprageneric classification of many ostracod taxa. The present study concentrates on the diverse extant cytheracean family the Cytheruridae, whose origins are in the earliest Mesozoic-latest Palaeozoic, but it is clear that many contemporary cytheracean families present similar problems. This review clarifies the previous taxonomic confusion and obfuscation by demonstrating that many of these genera are spurious having been erected on specific rather than generic morphological criteria. Many of them are best accommodated within the extant genus Eucytherura Müller, 1894. Most of the cytherurid genera known from the Liassic deposits of NW Europe can be traced back to these Triassic assemblages. In considering the origin and earliest evolution of the Cytheruridae, we note that some Triassic taxa share characteristics typical of both the Cytheruridae and the Bythocytheridae and it is suggested that the former may have arisen from the latter family during the latest Permian or earliest Triassic. We also note that the palaeoenvironmental interpretation of many of the Triassic deposits is brackish-water, marginal marine. J. Micropalaeontol., 19:(2): 139-152, December 2000.
\end{abstract}

\section{INTRODUCTION}

The family Cytheruridae G. W. Müller, 1894 is one of the most diverse extant families of ostracods with a fossil record extending back to the Early Mesozoic or possibly the latest Permian. Today they are almost exclusively marine, although there are some euryhaline species. During the Cenozoic the family was almost equally diverse in shelf and deep-sea environments. Mesozoic cytherurids seem to have been largely confined to shelf depths but shallow, brackish-water taxa are also known. This paper is limited to a consideration of Permian, Triassic and earliest Jurassic taxa.

In an attempt to establish the phylogenetic origin of the cytherurids we have re-evaluated the available published descriptions of Triassic marine and marginal-marine cytheracean taxa in a literature search of global scope. In this study we have considered a large number of genera and species, many of which are discussed here. We have found it necessary to synonymize a number of genera and also entire families as Whatley \& Moguilevsky (1998) did in a similar study of the Limnocytheridae. Within these Triassic assemblages we recognize some of the earliest representatives of the Cytheruridae. With some taxa we have experienced difficulties in determining their familial status. This is only to be expected early in the adaptive radiation of a superfamily and that of the Cytheracea is no exception (Whatley \& Stephens, 1976; Whatley, 1988).

The first major evolutionary radiation within the Cytheruridae is recognized to have taken place during the latest Triassic to Early Jurassic (Whatley et al., 1993), with some of these newly established genera surviving to the present day (e.g. Cytheropteron, Eucytherura). A large number of post-Palaeozoic cytheracean ostracod families can be traced back to the earliest Mesozoic, following the final extinction of many 'palaeocopid' ostracods by the close of the Permian (Whatley \& Stephens, 1976). Some authors signally failed to recognize that many of these early Cytheracea belonged to pre-existing post-Triassic genera and placed them in a series of spurious new genera. This is particularly true of the marine and euryhaline assemblages of Central, East and SE Europe. One of the consequences is that these 'new' genera appear to be stratigraphically restricted to the Triassic. Furthermore, many of the new genera have been erected on the basis of what we regard as specific characteristics and this is supported by the observation that many of them are mono-specific and, in some cases, were erected on a single specimen. The true suprageneric position of these taxa has, therefore, been obscured and the phylogenetic significance of these assemblages has only recently become apparent. The problem is compounded by the fact that these new taxa were placed in new families that were also stratigraphically confined to the Triassic. Many Liassic species, as demonstrated below, were also placed in new genera restricted to the Early Jurassic and we have synonymized a number of them.

The Late Palaeozoic demise of the 'palaeocopids' and other ostracod groups resulted in the emergence of typical Mesozoic assemblages, many of which have not previously been recorded in pre-Iurassic sediments. It would appear that their 'absence' from Triassic sediments was an artefact caused by misidentification and mis-interpretation. We believe that it is now possible to establish the antiquity, if not necessarily the origin, of the Cytheruridae within these Triassic assemblages.

The taxonomic problems outlined above have been compounded further by the fact that fully marine Triassic sequences are rather rare in NW Europe, so that most attention has been directed towards marginal-marine or freshwater ostracod assemblages (e.g. Beutler \& Gründel, 1963). Although most modern post-Liassic cytherurids (with notable exceptions) are marine, it now seems that some of their earliest representatives inhabited brackish-water marginal-marine environments. Marine sequences from the Early Mesozoic Tethys were largely unknown or ignored by European workers prior to the last 30 years. European studies in the epicontinental extension of Tethys, mainly by Kozur and colleagues (Kozur, 1968a,b, 1970a,b, 1971, 1972a, 1973; Kozur \& Nicklas, 1970; Kozur et 
al., 1974) epitomised the problems outlined above with, what is in our opinion, unnecessary 'splitting' at generic level. Subsequently, Kristan-Tollmann (1972, 1983, 1986, 1989) KristanTollmann \& Hasibuan, (1990), Kristan-Tollmann \& Gramann (1992), Kristan-Tollmann et al. (1991a,b) have extended our knowledge of Tethyan faunas through studies of Triassic marine deposits from the European Alps, Iran, Indonesia, China, Australia and New Zealand (see review in Kristan-Tollman, 1988). Most importantly she illustrated many Triassic taxa using scanning electron micrographs which are a significant improvement on the poorer quality reflected light microscope illustrations of earlier workers. Sohn $(1968,1970,1987)$ has also added valuable information on Triassic ostracods from Israel, Pakistan and Alaska respectively. Basha (1982) reported Triassic ostracods from Jordan. A number of papers describe Triassic ostracodes from ODP Leg 122 of NW Australia (CrasquinSoleau et al., 1990; Crasquin-Soleau \& Dépêche, 1992; Dépêche \& Crasquin-Soleau, 1992; Kristan-Tollmann \& Gramann, 1992). Marine Triassic ostracods have also been described from China (Guan, 1985; Zheng, 1988).

The Cytheruridae belong to the Superfamily Cytheracea (Order Podocopina, Ordovician to Recent) which dominate most post-Palaeozoic marine assemblages. The Cytheracea are characterized, among other features, by a vertically aligned row of four (rarely three or five) adductor muscle scars. The majority of Palaeozoic ostracods are distinguished by the possession of a sub-circular, irregularly arranged group of between 10 and 100 individual muscle scars, the only known Palaeozoic cytheracean ostracods are the Permianidae, the Limnocytheridae (Whatley \& Moguilevsky, 1998) which are non-marine, and the marine Bythocytheridae. The Permianidae are characterised by a vertically aligned row of three and the Bythocytheridae by five adductor muscle scars, while the Limnocytheridae like virtually all other Cytheracea have four vertically aligned adductors. It is our contention that the Bythocytheridae were the root stock which, during the Late Palaeozoic or Early Mesozoic interval, gave rise directly or indirectly to all other Cytheracea and that one of the earliest recognizable cytheracean families is the Cytheruridae.

Conventionally, three subfamilies are recognized within the Cytheruridae: the Cytherurinae, the Cytheropterinae (Hanai, 1957) and the Paracytherideinae (Mandelstam, in Orlov, 1960) (although some authors accord the latter separate familial status while others would include additional subfamilies such as the Late Cretaceous to Recent Oculocytheropterinae Bate \& Coleman, 1975 and the Jurassic to Recent Eucytherurinae Puri, 1974. The present authors contend that the majority of cytherurid species identified in the Triassic belong to the Cytherurinae while some are certainly, and others possibly, members of the Cytheropterinae. The family is known to be well established by the Early Jurassic. The Paracytherideinae are believed to have their earliest record in the Cretaceous and are not considered further in this study.

Unfortunately, many of the specimens figured in the literature on Triassic ostracods are often poorly illustrated and/or poorly preserved. As an additional complication, it is now clear that few of the types or specimens illustrated by Kozur and his colleagues were deposited in accessible collections and many are now certainly lost (Kozur, pers. comm.). Therefore, it is not possible to re-examine the majority of the type specimens and we are left with only the original illustrations, type descriptions and personal communications with the original authors. There are very few descriptions of taxonomically important internal features such as adductor muscle scars or hingement. Nevertheless, we believe that it is possible to draw important conclusions based on external features and gross carapace morphology. Hingement in Early Mesozoic cytheracean ostracods is generally lophodont, more rarely merodont. In the following sections we discuss the validity of many Permian to Early Jurassic genera. In many cases the type material is lost or was never curated. A complete taxonomic revision would warrant re-collection from all of the type localities combined with an exhaustive search of museum collections. We have chosen not to figure the few taxa that are available since they are already well illustrated in the literature. We have fully referenced the type description of each taxon discussed, since only through observing the original illustrations can the taxonomic problems be fully appreciated. We hope that this paper will stimulate further research on an important period in ostracod evolution

It is our opinion that many of the species recorded from the marginal-marine and marine Triassic deposits world-wide can easily be accommodated within already existing genera originally described from younger strata. Many previous taxonomic studies have obscured true evolutionary relationships by not distinguishing between generic and specific criteria. We have adopted the taxonomic philosophy outlined by Whatley \& Ballent (1996) in which generic characters are of kind while specific characters are of degree. Clearly there is scope for future research into the Early Mesozoic development of cytheracean ostracods, a fundamentally important period in their evolution.

\section{SYSTEMATIC DISCUSSION}

What follows, in alphabetical order, is an evaluation of a number of Late Palaeozoic-Early Mesozoic genera that are possible candidates for inclusion within the Cytheruridae. Some are accepted as members of the family while others are rejected. Genera which we consider valid, whatever their family, are given in titulo underlined and are diagnosed, those that we consider valid but which only occur in sediments younger than Early Jurassic are not diagnosed. The family to which we believe the valid taxa belong is also given and modern diagnoses of the Cytheruridae and its two relevant subfamilies are also presented. $\mathrm{LV}$, left valve; $\mathrm{RV}$, right valve. The following convention is used to describe ostracod size (in adult specimens)

Very small $<0.4 \mathrm{~mm}$

Small $0.4-0.5 \mathrm{~mm}$

Medium $0.5-0.7 \mathrm{~mm}$

Large $0.7-1.0 \mathrm{~mm}$

Very large $>1.0 \mathrm{~mm}$

\section{Suprageneric classification}

Class Ostracoda Latreille, 1802

Order Podocopida Müller, 1894

Suborder Podocopina Sars, 1866

Superfamily Cytheracea Baird, 1850

Family Cytheruridae Sars, 1925 
Diagnosis. Small. Calcification ranging from thin to thickshelled. Subovate, subrhomboidal, subquadrate to subrectangular. Often with caudal process and many with flattened venter. Right valve only slightly larger than left. With or without subcentral tubercle. Ranging from non-alate to very strongly alate ventro-laterally or postero-ventrally. Blind or with eye spots or strong eye tubercles. Valves smooth, punctate, reticulate, costate to strongly carinate or combinations of these. Normal pore canals ranging from simple (the most common) to primitive sieve-type. Radial pore canals rather few, simple, often sinuous and with false canals. Mainly avestibulate but small vestibula may be developed at either end. Inner margin usually regular but may be very irregular. Frontal scar ovate, reniform to $v$-shaped and sometimes subdivided. Hinge lophodont or merodont, often strongly modified and sometimes secondarily adont, very rarely pentadont.

Subfamily Cytherurinae Sars, 1925

1968 Judahellidae Sohn: 12

1971 Kerocytheridae Kozur: 48

1972b Trachycytherinae Kozur: 13

1973 Mostlerellidae Kozur: 19

Diagnosis. Carapace generally subrectangular in lateral view and usually without strong alae. Caudal process often pronounced. Smooth to strongly ornamented with ribs, tubercles, etc. Vestibula small or absent. Hinge as for family but never adont. Inner margin parallel to widely divergent. Radial pore canals often long, sinuous with false canals. Eye tubercles frequently well developed in ornate taxa.

Subfamily Cytheropterinae Hanai, 1957

Diagnosis. Carapace subovate, with dorsal margin often rounded, to subquadrate and sub-rectangular. Feebly ornamented, smooth to punctate or reticulate. Usually strongly alate or tumid ventro-laterally. Small vestibula usually present. Hinge usually antimerodont but often modified. Without eye tubercles.

\section{Generic classification}

Genus Blomella Kozur, 1973

?1956 Speluncella Schneider; Mandelstam et al.: 120.

Type species. Speluncella sulcata Kozur, 1968 b (p. 509, pl. 1, figs 3, 8, 23, 24, 27-29).

Diagnosis. Carapace small to medium size, smooth, $L V>R V$. Ventral margin straight; anterior, dorsal and posterior margins form a highly arched outline in lateral view. Ventral margin flat and extended laterally into distinct flanges. Hinge short, lophodont.

Remarks. The type species, Blomella sulcata, was originally assigned to Speluncella Schneider (in Mandelstam et al., 1956) which Whatley \& Moguilevsky (1998) place in the Limnocytheridae, Timiriaseviinae. B. sulcata is at least outwardly similar to members of the Timiriaseviinae. The type species is somewhat cytheropterine (reminiscent of Modern deep-sea taxa such as Cytheropteron testudo) but Kozur (pers. comm., 1997) states that the genus was recovered from brackish water sediments and it is very rare for fossil or Recent members of Cytheropteron or its allies to occur in environments of reduced salinity. Although Whatley \& Moguilevsky (1998) did not include Blomella in their review of the Limnocytheridae, it is probably a valid member of that family and not a cytherurid. Blomella may be a junior synonym of Speluncella but for the time being we accept it as a valid taxon but not a member of the Cytheruridae.

\section{Genus Citrella Oertli, 1959}

Type species. Citrella nitida Oertli, 1959 (p. 118, pl. 2. figs 16-19, p.117, text-fig. 3).

Diagnosis. Carapace small, ovate in lateral view with short, sharp caudal process posteriorly, LV overlaps RV along dorsal and ventral margins. Lateral surface smooth. Ventro-lateral margin slightly extended. Anterior and posterior marginal pore canals few and straight. Four ovate adductor muscle scars and two frontal scars. Lophodont hinge.

Remarks. Citrella is a cytheropterine genus with smooth hinge elements which was originally described from Middle Jurassic sediments in France. It has superficial similarities with Cytheropterina Mandelstam (in Mandelstam et al., 1956) but the two genera are certainly not synonymous. Kozur \& Bolz (in Kozur, 1971) described two species, Citrella? lata (p. 19, pl. 3, figs. 4-5) and Citrella? bairdiaformis (p. 18, pl. 3, figs 2-3) which they assigned, questionably, to this genus. Kozur (pers. comm., 1997) confirmed that these species were recovered from Triassic (Late Norian) marine sediments. A similar species, Cytheropteron? triassica Kozur (in Kozur, 1971) was described from what were 'probably marine sediments' (Kozur, pers. comm., 1997); the species has a lophodont hinge and cannot, therefore, belong to Cytheropteron sensu stricto although it is certainly cytheropterine and probably belongs to Citrella. Kozur (pers. comm., 1997) now concurs with this conclusion.

Speluncella? ampelsbachensis, from 'probable marine Late Norian sediments' (Kozur, pers. comm., 1997), was described by Kozur \& Bolz in the same publication (Kozur, 1971, p. 46, pl. 3, figs 6-7) and is probably congeneric. A number of similar species are also present in the Early Jurassic sediments of the Mochras Borehole, Wales (Boomer, 1989 and unpublished data) and these almost certainly constitute a distinct group within the Cytheropterinae. It is our opinion, therefore, that the genus Citrella ranges from the Late Norian to the mid-Bathonian and possibly to the Tithonian (Pokorny, 1973).

Genus Cytheropteron Alexander, 1933

1964 Infracytheropteron Kaye: 105.

1974 Lobosocytheropteron Ishizaki \& Gunther: 32

Diagnosis. Subcircular, subovate or subrhomboidal. With or without caudal process. Alate or, alternatively, very tumid ventro-laterally. Smooth, punctate, rarely reticulate or delicately ribbed. Blind. Median element of hinge sometimes strongly crenulate. Radial pores relatively few, well spaced, straight and simple.

Remarks. The genus Cytheropteron has been reported in Triassic assemblages as two distinct subgenera, Cytheropteron (Cytheropteron), Cytheropteron (Stykella); the nominative subgenus has its oldest certain record in the Toarcian (Cytheropteron alafastigatum Fischer, 1962, falciferum Zone, Mochras Borehole, Great Britain; Boomer, 1989). The species Cytheropteron? triassica described by Kozur (1971) is almost certainly not a valid member of that genus. Bate \& Coleman (1975) erected the subfamily Oculocytheropterinae to incorporate the eyed $C y t$ ther- 
opteron-like species, i.e. the Late Cretaceous to Recent Oculocytheropteron Bate and they included the Liassic genera Rutlandella and Wellandia (see below). In the following sections we synonymize the latter two genera with Eucytherura which is accommodated within the Cytherurinae. The Oculocytheropterinae are not considered further here. Lobosocytheropteron is based solely on the fact that species such as C. alatum Sars, 1866 have a bend in the median element of the hinge. We do not consider this to be a generic characteristic.

Subgenus Cytheropteron (Infracytheropteron) Kaye, 1964 Type species. Cytheropteron (Infracytheropteron) exauisita Kaye, 1964 (p. 105, pl. 5, figs 9-10).

Remarks. The subgenus Infracytheropteron (originally erected as a monospecific Early Cretaceous taxon) was differentiated from Cytheropteron on the basis of hingement which was said to consist of a smooth bar in each valve, produced by the enlargement of the selvage and valve margins. This may have been erroneously described from a juvenile specimen, no internal views were figured in the type description although the duplicature was described as narrow. A number of Liassic species have subsequently been assigned to this subgenus (see Bate \& Coleman, 1975; Knitter, 1983) an assessment which appears to be based largely on external characteristics, the status of this taxon is at best questionable and we consider it to be a junior synonym of $C y$ theropteron.

Subgenus Cytheropteron (Stykella) Kozur, 1971

Type species. Cytheropteron (Stykella) sevatica Kozur, 1971 (p. 20, pl. 3, fig. 8).

Remarks. This was erected as a subgenus of Cytheropteron to accommodate a single species. The straight hinge line precludes its inclusion in Cytheropteron. It is described as having a 'hemimerodont' hinge and from the type figures it clearly possesses an eye node, a caudal process and a ventro-lateral extension which terminates posteriorly in a small blunt spine. Its shape disqualifies it for inclusion within Aversovalva Hornibrook, 1952 or Oculocytheropteron Bate, 1972. In all characteristics it clearly belongs within Eucytherura Müller.

Genus Dettermania Sohn, 1987

Type species. Dettermania truncata Sohn, 1987 (p. 11, pl. 7, figs 4-15).

Remarks. Sohn (1987) described the type species of Dettermania together with two similar species which he assigned to Covracythere (Gramm, 1975) from the marine Triassic deposits of Alaska. All three species are morphologically similar and it is possible that they are congeneric. The genus Covracythere is, without doubt, a bythocytherid (possessing five adductor muscle scars) and was originally described along with two other bythocytherid genera, Racevetina and Acvocaria, from the Far East of the Former Soviet Union (Gramm, 1975). All three species figured by Sohn possess median sulcii and straight dorsal margins, indicating that they may belong within the Bythocytheridae. However, without supporting details of the muscle scars, any such assignments $n$ ?st remain uncertain.

No details of the muscle suars or hingement of Dettermania are available. The carapace shape and external morphology is distinct and strongly suggests that it is congeneric with Mockella
Bunza \& Kozur, 1971, as is Hasibuana Kristan-Tollmann (in Kristan-Tollmann \& Hasibuan, 1990; see below). Dettermania differs slightly from Mockella in that it lacks secondary intercostal ornament, however, we conclude that this is a specific character and therefore Dettermania is a junior synonym of Mockella.

Genus Eocythereis Anderson, 1964

Type species. Eocythereis vertebralis Anderson, 1964 (p. 145, pl. 13, figs 79-80).

Remarks. Anderson (1964) placed this genus in the Trachyleberididae which has its origins in the Early Cretaceous (Whatley et al., 1993). Recent examination of the type material (originally erected on a single carapace), from the Rhaetian, Cotham Beds of Warwickshire, Great Britain (Anderson, 1964) reveals that it is congeneric with (and a junior synonym of) Eucytherura.

\section{Genus Eucytherura Müller, 1894}

1964 Eocythereis Anderson: 145.

1969 Nanacythere (Domeria) Herrig: 1085.

1969 Nanacythere (Nanacythere) Herrig: 1080.

1971 Gramella Kozur: 21.

1971 Movschovitschia Kozur: 29.

1971 Sohnetta Kozur: 42

1971 Cytheropteron (Stykella) Kozur: 20

1972a Grammicythere Kozur: 642 (nom. nov. for Gramella)

1975 Grammanicythere Gründel: 364

1975 Nanacythere (Goniocythere) Michelsen: 201

1975 Rutlandella, Bate \& Coleman: 34.

1975 Wellandia Bate \& Coleman: 32.

1987 Paratrachycythere Park: 63.

Type species. Cythere complexa Brady, 1867 (by subsequent designation: Alexander, 1936).

Diagnosis. See emended diagnosis in Ayress et al. (1995).

Remarks. A long-ranging genus originally described from Recent sediments in the Gulf of Naples (Müller, 1894) although the type species, Eucytherura complexa (Brady, 1867), was only later designated by Alexander (1936). The genus is distinguished from most other cytherurid taxa by its quadrate carapace in lateral view, which is only moderately inflated in dorsal view and the dominance of reticulate ornamentation. However, up to three longitudinal ribs (generally dorso-median or median and ventro-lateral in position) may also be present. Most species possess a strong tubercle or spine at the posterior apex of the ventro-lateral rib which itself may become quite inflated. Many species are characterized by the presence of a strong eye tubercle but Cenozoic and Recent species which live in deep water are blind. We prefer to include Eucytherura within the Cytherurinae, discussion of the status of the subfamily Eucytherurinae can be found in Maddocks \& Steineck (1987).

We consider Eucytherura to be a senior synonym of the following Early Mesozoic taxa (with the family they were originally assigned to, if available): Eocythereis (Trachyleberididae), Gramannicythere, Grammella, Grammicythere, Movschovitschia, Nanacythere (Domeria) (Cytheridae), Nanacythere (Goniocythere), Paratrachycythere, Rutlandella (Oculocytheropterinae), Wellandia (Oculocytheropterinae) and a number of Early Jurassic species assigned by some workers to Acrocythere 
(e.g. Michelsen, 1975). All the above spurious taxa, and others erected in the subsequent Mesozoic and Cenozoic are, in our opinion, the product of confusing generic and specific criteria. Gründel (1975) claimed that all Mesozoic Eucytherura are vestibulate, however, our own observations do not support this statement. We consider the subgenus Eucytherura (Vesticytherura) (Gründel, 1964) to be an unnecessary taxon.

\section{Genus Falloticythere Kozur et al. 1974}

Type species. Falloticythere mulderae Kozur et al. 1974 (p. 36, text figs 19a,b,d; pl. 2, figs 9-13).

Remarks. This genus was placed in the Cytherissinellidae by Kozur et al. (1974) and this family has now been subsumed within the Limnocytheridae (Whatley \& Moguilevsky, 1998). Kozur et al. commented on the presence in the type species, Falloticythere mulderae, of an antero-ventral node and an antero-median to mid-anterior node, these features produce a mid-valve sulcus which is found in most bythocytherid and many limnocytherid taxa. The hinge was described as lophodont with weak terminal teeth. The type species occurs in salinities ranging from marine to continental hyposaline (Kozur, pers. comm.).

Although possibly a cytherurid, and without internal details it is impossible to be sure, we believe that the weak hingement and carapace shape are best accommodated within the Bythocytheridae, and Falloticythere may be a junior synonym of Monoceratina Roth, 1928. As with Covracythere a number of Triassic cytheracean taxa appear to share common bythocytherid and cytherurid characteristics, indicating the possible origin of the Cytheruridae from bythocytherid stock in the Late Permian or earliest Triassic.

Genus Gramannicythere Gründel, 1975.

Type species. Lophodentina? bachi Gramann, 1962 (p. 195, fig. 2; pl. 2, fig. $5 \mathrm{a}-\mathrm{c}$ ).

Remarks. This is synonymous with Nanacythere (Goniocythere) Michelsen, 1975 which was published a few months later. The genus comprises a few, mainly Pliensbachian, cytherurid species with a strongly angular development in the lateral primary ribbing. The taxonomic status of both Nanacythere (Domeria) Herrig, 1969 and Nanacythere (Nanacythere) are discussed below. We consider Gramannicythere and, therefore, Nanacythere (Goniocythere) to be junior synonyms of Eucytherura. Although possibly a valid taxon (and we consider it as such in the summary table), the lack of descriptive and illustrative material makes it impossible to provide a meaningful diagnosis at this time.

Genus Grammicythere Kozur, 1972a nom. nov. Type species. Gramella hungarica Kozur, 1971 (p. 22, pl. 1. fig. 1; pl. 4, fig. 3).

Remarks. Grammicythere replaced Grammella Kozur, a junior objective homonym of a bryozoan. The original publication also mis-spelt the name as Gramella. The type species possesses a straight to slightly convex dorsal margin and reticulate lateral surfaces with a ventro-lateral rib, it clearly belongs within the Cytherurinae and seems best accommodated within Eucytherura, although no eye-spots were recorded (many modern species of Eucytherura lack eyes, especially those which occur in deep water). Kozur (1971) states that it is closely related to Lutkevichinella Schneider (in Mandelstam et al., 1956) a genus which Whatley \& Moguilevsky (1998) have shown to be a limnocytherid. However, on the basis of the very poor illustrations of the type species of Grammicythere it is difficult to observe any points of similarity with Lutkevichinella. Notwithstanding this, we believe the genus to be another junior synonym of Eucytherura.

\section{Genus Gruendelicythere Kozur, 1971}

Type species. Gruendelicythere ampelsbachensis Kozur \& Bolz n. sp. in Kozur, 1971 (p. 24, pl. 6, figs 6-10).

Diagnosis. Carapace small, rather elongate, dorsal and ventral margins straight converging slightly posteriorly. Posterior and anterior margins rounded in lateral view, compressed in dorsal view. Lateral surface bears marked reticulate nodes and sulcii, the largest of which are in the mid- to postero-ventral region. They do not extend beyond the dorsal margin in lateral view. Ventral surface flat and broad. Hinge probably lophodont.

Remarks. The type species is a very small cytherurid and, although it resembles Eucytherura, it differs from most species of that genus in possessing particularly large nodes and tubercles for such a small ostracod. It has a slightly produced posterior with compressed anterior and posterior margins. Kozur (1971) refers to the similarity of its noding to Judahella Sohn, 1968 but the distribution and nature of the noding in the two genera is quite different, as is the carapace outline (most species of Judahella have well developed nodes which extend beyond the dorsal margin) and the similarity is probably convergence. In the shape of the carapace and the distribution of nodes it differs significantly from the nodose Liassic cytherurid Trachycythere Triebel \& Klingler, 1959. There are superficial similarities with Cretaceous and Cenozoic genera, such as Chapmanicytherura Weaver, 1982, Hemingwayella Neale, 1975 and Parahemingwayella Dingle, 1984 but Gruendelicythere differs sufficiently from all the above comparitors for us to consider it valid. A species assigned to this genus has been described from the Late Permian of northern Hungary (Kozur, 1985).

\section{Genus Hasibuana Kristan-Tollmann (in Kristan-Tollmann \&} Hasibuan, 1990)

Type species. Hasibuana asiatica Kristan-Tollmann (in KristanTollmann \& Hasibuan, 1990) (p. 176, pl. 1, figs 1-5).

Remarks. The type species possesses a well-developed pair of diagonal, lunate ribs with weak intercostal reticulation; a poorly developed eye-spot is also present. The carapace has a straight dorsal and highly convex ventral margin and in this respect is very similar to Dettermania in lateral outline. However, it lacks the median sulcus of that genus. Kristan-Tollmann (in KristanTollmann \& Hasibuan, 1990) noted that Hasibuana differs from Dettermania in possessing an eye-spot, and antero and posteromarginal ribs. We consider these differences to be of specific rank only and, therefore, that Hasibuana, like Dettermania, is a junior synonym of Mockella based on carapace shape, size and distribution of major ribs.

Genus Judahella Sohn, 1968

1968 Ophthalmonodella Knüpfer \& Kozur: 322

1971 Judahella (Costahella) Kozur: 42 
1971 Mostlerella Kozur: 37

1985 Buekkella Kozur: 31

Type species. Judahella tsorfatia Sohn, 1968 (p. 15, pl. 3. figs 2021).

Diagnosis. Small, oval to triangular in lateral view. Dorsal margin straight, ventral margin convex, strongly so in some species. Anterior margin flat to broadly rounded. Greatest length near dorsal margin, greatest height near anterior margin. The valves are sometimes smooth but more commonly reticulate and bear a number of distinct swellings or nodes which are consistently developed within species. In many species these nodes extend beyond the dorsal margin in lateral view. There may also be a longitudinal rib present ventro-laterally. Hinge merodont. Muscle scars a vertically aligned row of four.

Remarks. Sohn (1968) originally placed this genus in the Palaeocopida (Superfamily unknown) and in a new family, the Judahellidae. Sohn discussed its possible relationship to a number of genera such as Cornigella Warthin, 1930 and Trachycythere. We consider Judahella to be a cytheracean, and almost certainly a cytherurid, characterized by a small, straighthinged carapace with 3-4 large dorsal tubercles extending beyond the dorsal margin.

Kozur (1968b, p. 502) noted that Casachstanella scungayica Schleifer, 1966, the type species of that genus, is a brackishwater form related to Judahella. Kozur (1970a) later considered Judahella to be a junior synonym of Triassinella Schneider (in Mandelstam et al., 1956), however, Whatley \& Moguilevsky (1998) placed Triassinella in the Limnocytheridae which precludes synonymy with the present genus. Confusingly, in the same paper Kozur (1970a) also established Judahella as a subgenus of Triassinella. The species illustrated by KristanTollmann et al. (1991b, pl. 8, fig. 1) as Triceratina fortenodosa (Urlichs, 1972) is a species of Judahella.

Sohn (1968) discussed the possible relationship between Judahella and Liasssic species of Trachycythere Triebel \& Klingler (1959) which also bear large tuberculae. However, the disposition of tuberculae in the two genera is quite different and we believe that this similarity is merely homeomorphic (see further discussion on Trachycythere below). Judahella andrussovi Kozur \& Bolz, 1971 of Kristan-Tollmann et al., 1991a,b resembles another Liassic genus, Paratrachycythere Park, 1987. That genus was named for its superficial similarity to the younger Trachycythere (Triebel \& Klingler), which is unfortunate because the two Liassic taxa are quite different, particularly in hingement, size and lateral outline. Neither genus can be confidently related to Judahella which we consider to be a valid cytherurid taxon. There is evidence that Judahella ranges back to at least the Late Permian of northern Hungary (Kozur, 1985). In the same publication a new genus was erected, Buekkella Kozur, which may be a junior synonym of Judahella.

Subgenus Judahella (Costahella) Kozur, 1971

Type species. Judahella (Costahella) hungarica Kozur, 197I (p. 28, pl. 2. fig. 6).

Remarks. Erected as a subgenus of Judahella Sohn, based on the presence of a rib below the four main dorsal tubercles. In our opinion this is at best a specific character, or common to a group of Judahella species, and the diagnosis of Judahella has been emended above accordingly. We consider the subgenus to be a junior synonym of Judahella.

Genus Kerocythere Kozur \& Nicklas, 1970

1972 Rekocythere Kristan-Tollmann: 46

Type species. Cythere raibliana Gümbel, 1869 (p. 184, pl. 6, fig. 36a).

Diagnosis. Carapace elongate, triangular in lateral view, greatest height near anterior margin. Dorsal margin straight, ventral margin convex, greatest length above mid-height. Carapace outline triangular in end view with greatest width across ventral surface. Surface of valves smooth or reticulate. Valves bear distinct circum-marginal ribs or flanges (which may be perforate, see Kristan-Tollmann et al., 1991a, pl. 2, figs 1,2), cardinal angles well marked and may bear projections. One species, Kerocythere bulbosa (Kristan-Tollmann, 1972), also possess large bulbous inflations anteriorly. Eye spots weak or absent. The hinge is very characteristic. The terminal elements in the LV are single smooth loculi, while the median element, a possibly denticulate bar, is extended distally (both anteriorly and posteriorly) into a large hemispherical boss.

Remarks. The genus was originally placed in the Trachyleberididae. In the type description Kozur \& Nicklas (1970) designated Cythere raibliana Gümbel, 1869 as the type species but did not figure any new specimens of that species. They figured three species, two of which were referred to Kerocythere n. sp.1 Bolz and Kerocythere n. sp.2 Bolz and the third to Kerocythere $\mathrm{n}$. sp. The reason for reference to Bolz on this publication is unclear.

Kerocythere sp.1 Bolz (Kozur \& Nicklas, 1970, pl. 2, fig. 1) possesses three distinct longitudinal ribs (dorsal, mid- and ventral), a denticulate anterior margin and a weak eye spot. Kerocythere sp. 2 Bolz (Kozur \& Nicklas, 1970, pl. 2, fig. 2) possesses a dorsal, ventral and antero-marginal rib. The dorsal part of the ventral rib displays a series of short vertical riblets. The antero-cardinal angle terminates in a small boss while the postero-dorsal cardinal angle possesses a short, dorso-ventrally projecting spine (an extension of the dorsal rib). Kozur \& Nicklas (1970) also figured material assigned to Kerocythere $\mathrm{n}$. sp. which is probably a juvenile of one of the aforementioned species.

According to Kozur \& Nicklas (1970), the genus possesses an amphidont hinge, this is both phylogenetically unlikely and entirely unsubstantiated by the illustrations. Indeed, the hingement appears to be peratodont (sensu Bate, 1972), whereby the median element is inflated terminally. Indeed, from the available illustrations it appears that the terminal teeth (in the right valve and terminal inflations of the median element in the left valve) are very strongly developed, although this may be an artefact of the illustration process (possibly retouched). The hingement is better illustrated in Kozur, 1971 (pls 7 \& 8), indeed pl. 7, fig. 5b shows a crenulate median element although this too may have been manually retouched. The hingement closely resembles that of certain Campanian to Recent taxa belonging to the Pectocytheridae, an essentially Southern Hemisphere and mostly Pacific family whose hinge is termed pentadont (Hanai, 1957), which seems to be synonymous with holoperatodont, the former having priority. We consider Kerocythere to be a valid 
cytherurid genus with a distinctive carapace outline, ornament and hingement.

Subgenus Kerocythere (Rekocythere) Kristan-Tollmann, 1972 Type species. Kerocythere (Rekocythere) bulbosa KristanTollmann, 1972 (p. 46, pl. 2, figs 6,7).

Remarks. A subgenus which was originally distinguished from Kerocythere sensu stricto by the presence of a median rib, which we consider to be a differentiating character at species level only. Furthermore, the type species is almost certainly a junior synonym of Kerocythere veghae Kozur, 1971 (in Bunza \& Kozur, 1971). Kristan-Tollmann (1972) made no reference to this species when erecting the subgenus nor did she reference the publication and it is probable that she did not see it before publishing her work. We do not accept the validity of this subgenus and have emended the diagnosis of Kerocythere to accommodate it.

\section{Genus Lophodentina Apostolescu, 1959}

Type species. Lophodentina lacunosa Apostolescu, 1959 (p. 814, pl. 3, figs 56,57).

Diagnosis. Carapace medium sized, well calcified, ovate to subrectangular in lateral view. Anterior and posterior margins broadly rounded, dorsum straight, venter sinuous to weakly concave. Carapace uniformly inflated without distinct marginal compression. External ornament variable but usually well developed as reticulae and a combination of longitudinal, transverse or marginal ribbing. Hinge straight, weakly merodont. Inner lamella of medium width.

Remarks. The genus was originally described from Liassic sediments in the Paris Basin and was placed within the Cytherinae. This medium-sized genus was named for its lophodont hingement which, in fact, now seems to be merodont with a weakly crenulate median element. Subsequently, Gramann (1962) assigned one new species (Lophodentina? bachi) and one undescribed Liassic species to this genus. Those latter two species we consider to belong to Eucytherura. The taxonomic status of Lophodentina remains in question but may be a valid genus. The earliest representatives of the genus are probably Liassic. Given its large size, carapace shape and lateral outline we do not consider this to be a cytherurid.

Genus Metacytheropteron Oertli, 1957

Type species. Metacytheropteron elegans Oertli, 1957 (p. 8, pl. 1, fig. 12).

Remarks. Metacytheropteron is a Middle Jurassic to Cretaceous member of the Cytheropterinae and, as such, is outside the scope of this study. However, Anderson (1964) assigned a Rhaetian species (Metacytheropteron nannodes) to this genus. We have now examined the type specimen of Metacytheropteron nannodes and consider that it belongs to the genus Procytherura Whatley, 1970. Since the genus does not occur in Permian or Triassic sediments a diagnosis is not included.

Genus Mockella Bunza \& Kozur, 1971

1981 Renicytherura Gründel: 543

1987 Dettermania Sohn: C11.

1990 Hasibuana Kristan-Tollmann; Kristan-Tollmann \& Hasibuan: 175 .
Type species. Mockella meulleri Bunza \& Kozur, 1971 (by subsequent designation; Kozur, 1973) (p. 8, pl. 1, fig. 12).

Diagnosis. Medium-sized carapace, dorsal margin slightly convex and sinuous, ventral margin strongly convex, $L V>R V$. Medianly sulcate, may have antero-central node in front of sulcus. Lateral surfaces smooth or finely punctate with median and ventro-lateral longitudinal ribs present, the latter parallels ventral margin. Eye spot may be well developed. Hingement lophodont, small vestibulum both anteriorly and posteriorly.

Remarks. The authors assigned a taxon as type species which was due to be published shortly afterwards (Mockella marinae), however, that publication never appeared (Kozur, pers. comm.). In 1973, Kozur subsequently designated Mockella meulleri Bunza \& Kozur, 1971 as the type.

The type species described and figured by Bunza \& Kozur (Mockella muelleri, p. 8, pl. 1, fig. 12) was originally assigned to the Glorianellidae which is now considered to be a junior synonym of the Limnocytheridae (Whatley \& Moguilevsky, 1998). From published illustrations and the original generic diagnosis, we infer that Mockella is a senior synonym of both Dettermania Sohn, 1987 and Hasibuana Kristan-Tollmann (in Kristan-Tollmann \& Hasibuan, 1990). Lord et al. (1993) figured a nomina aperta species of Renicytherura Gründel, 1981 from the Early Jurassic off Western Australia which may be congeneric. We therefore consider Mockella to be a senior synonym of Dettermania and Hasibuana and to be a valid genus of the Cytheruridae, Cytherurinae.

Genus Mostlerella Kozur, 1971

Type species. Mostlerella nodosa nodosa Kozur, 1971 (p. 38, pl. 4, figs $10,12,14,16$ ).

Remarks. Kozur assigned two new species to this genus. Both possess a very straight dorsal margin, bulbous swellings along the dorsal margin and a ventro-lateral rib. These features accord well with the emended diagnosis of Judahella (see above). Kozur originally described the genus as possessing a lophodont hinge, however, Kristan-Tollmann (1982) illustrated a number of Mostlerella species and emended the diagnosis to include a noridont hinge. We regard this genus as a junior synonym of Judahella.

\section{Genus Movschovitschia Kozur, 1971}

Type species. Movschovitschia norica Kozur \& Bolz, in Kozur, 1971 (p. 33 pl. 3, figs 9-14).

Remarks. Originally erected as a subgenus of Lophodentina, illustrations of the type species clearly show great similarity with the type species of Rutlandella (Rutlandella transversiplicata Bate $\&$ Coleman, 1975) which is a junior synonym of Eucytherura (see below). All of the species assigned to this genus are congeneric and we regard Movschovitschia as a junior synonym of Eucytherura.

Genus Nanacythere Herrig, 1969

1969 Nanacythere (Domeria) Herrig: 1085.

1975 Nanacythere (Goniocythere) Michelsen: 201.

Type species. Nanacythere simplex Herrig, 1969 (p. 1081, pl. 1, figs $3-4$, text figs 6,7 ).

Remarks. Nanacythere was originally described from mid- and Upper Liassic deposits in northern Germany (Herrig, 1969), it 
has not been recorded from the Triassic or the Lower Liassic and it appears to be restricted to the Pliensbachian and Toarcian. Three subgenera have been described to date and we consider all three to be junior synonyms of Eucytherura.

Genus Noricythere Bolz \& Kozur (in Kozur, 1971) Type species. Noricythere hartmanni Bolz \& Kozur, in Kozur, 1971 (p. 54, pl. 7, figs 1,4,5; pl. 8, figs 4,7).

Remarks. Noricythere is a junior synonym of Kerocythere Kozur $\&$ Nicklas, 1970. The type species bears regular punctation and small nodes on the lateral surfaces with slight inflation of the circum-marginal rib at the cardinal angles. However, some species assigned to this genus, such as Noricythere mostleri Bolz \& Kozur, 1971 are best assigned to Eucytherura.

Genus Ophthalmonodella Knüpfer \& Kozur, 1968 Type species. Ophthalmonodella reticulata Knüpfer \& Kozur, 1968 (p. 323, pl. 1, figs 3a-c, 10, 13-24).

Remarks. The type description was published just a few months after Judahella Sohn of which it is acknowledged to be a junior synonym (Kozur, 1970a, p. 404). The type illustrations show details of the adductor muscle pattern with four elongate oval scars.

\section{Genus Paratrachycythere Park, 1987}

Type species. Paratrachycythere pseudotubulosa Park, 1987 ( $\mathrm{p}$. 63, pl. 3, figs 19-22).

Remarks. This taxon was originally named for its alleged similarity to Trachycythere tubulosa Triebel \& Klingler, 1959. The lateral tubercles which are the main feature linking the two genera can also be found, albeit weakly developed, in Eucytherura species from the Liassic of the Danish Embayment (Michelsen, 1975 as Acrocythere). We believe this feature is homeomorphic and that the two genera (Eucytherura and Trachycythere) are distinct and probably unrelated. We consider this genus to be a junior synonym of Eucytherura.

The suprageneric position of genera such as Trachycythere remains in question. It was originally assigned to the Trachyleberididae, however, that family is now considered to range from the Early Cretaceous.

\section{Genus Procytherura Whatley, 1970}

Type species. Procytherura tenuicostata Whatley, 1970 (p. 323, pl. 6, figs 1-8) .

Diagnosis. Carapace small, rounded, ovate elongate outline in lateral view. Dorsal and ventral margins weakly convex. Ornament variable but usually dominated by longitudinal ribs with secondary reticulation. Lateral projections rare. Hinge lophodont. Vestibulate.

Remarks. This valid cytherurid genus, which extends from the latest Triassic through to the Cretaceous and possibly into the Early Cenozoic, lacks the distinct eye tubercle and posteroventral projection of Eucytherura. It can also be distinguished by its more elongate, lanceolate carapace lateral outline. It differs from Cytherura Sars in the presence of vestibula. Ornament is dominantly of ribbing rather than reticulation, although some species are smooth or very weakly ornamented. Recent examination of Anderson's (1964) Rhaetian material has revealed that Metacytheropteron nannodes Anderson belongs to Procytherura, thus extending the range of this genus back to the Late Triassic.

Genus Rutlandella Bate \& Coleman, 1975

Type species. Rutlandella transversiplicata Bate \& Coleman, 1975 (p. 34, pls 13.7-13.10, 13.12, text figs 14a,b, 15, 16).

Remarks. This genus was erected on characteristics which are essentially specific. Within the literature there are a number of closely related species which have been assigned to genera such as Rutlandella, Movschovitschia and Eocythereis. We do not consider that these species warrant separate generic status and, therefore, Rutlandella is placed in synonymy with Eucytherura.

\section{Genus Simeonella Sohn, 1968}

Type species. Simeonella brotzenorum Sohn, 1968 (p. 23, pl. 2, figs $1-4,6-8,12-22$ ).

Remarks. Simeonella Sohn, 1968 was described from the Triassic of Israel. The carapace is sub-rectangular in lateral view, inflated laterally with a reticulate external surface and an antimerodont hinge. Sohn (1968) placed it questionably in the Cytheruridae, while Bunza \& Kozur (1971) placed it in the Progonocytheridae. Sohn suggested that Scabriculocypris Anderson, 1940 and Tchunguania Zhong, 1964 may be synonymous with Simeonella. Tchunguania, however, is a non-marine genus belonging to the Permianidae, which is characterized by the possession of 3 adductor muscle scars (Whatley \& Moguilevsky, 1998). Sohn also placed some Chinese species of Gomphocythere described by Zhong (1964) into Simeonella. We disagree with Sohn on these possible synonymies. We follow Whatley \& Moguilevsky (1998) who placed Simeonella in the Cytherissinellidae in possible synonymy with Lutkevichinella Schneider (in Mandelstam et al., 1956). They also subsumed the Cytherissinellidae within the Limnocytheridae, Limnocytherinae. The adductor muscle scar pattern clearly precludes the inclusion of this genus within the Cytheracea and therefore the Cytheruridae.

Genus Sohnetta Kozur, 1971

Subgenus Sohnetta (Sohnetta) Kozur, 1971

Type species. Sohnetta (Sohnetta) meulleri Kozur, 1971 (p. 42, pl. 2, fig. 8).

Remarks. From the type figure and description, the genus possesses a very small, sub-triangular carapace and the hinge is probably lophodont. In our opinion this taxon certainly belongs to the Cytherurinae (Cytherurinae). Only one figure was given of the holotype which is sub-triangular in lateral outline, has a slightly convex dorsal margin and two dominant longitudinal ribs extending from postero-dorsal to antero-ventral. The type species is easily accommodated within Eucytherura. KristanTollmann (1983, p. 153) placed the type species into Judahella (Costahella), however, the lack of tubercles and convex dorsal margin distinguish this species from Judahella. We consider Sohnetta to be a junior synonym of Eucytherura.

Genus Boogaardella Kozur, 1971

Type species. Sohnetta (Boogaardella) triassica Kozur \& Bolz n.sp. in Kozur, 1971 (p. 45, pl. 5, figs 1, 3-5).

Diagnosis. Carapace small, triangular to sub-rectangular in lateral view, dorsum and venter straight and convergent 
posteriorly, anterior and posterior margins broadly rounded. Carapace only weakly inflated, trapezoidal in dorsal view, broadest in posterior $1 / 4$. Lateral surfaces reticulate and bear strong ribs and minor tubercles. Strong ventro-lateral rib extends along anterior margin. Smaller transverse ribs originate at postero-dorsal tubercle. Internal features unknown.

Remarks. The subgenus Sohnetta (Boogaardella) Kozur was erected in the same publication as Sohnetta (Sohnetta). However, the poor quality of the illustrations precludes a complete review of the relationship between these taxa. In our opinion the type species, Sohnetta (Boogardella) triasica Kozur, is clearly a cytherurid characterized by its small carapace size and ornamentation. Although external ornament is similar to that of other taxa discussed herein we have retained this as a valid genus due to the distinctly different carapace shape which is much more angular in lateral view that that of Judahella. More importantly the outline in dorsal/ventral view (Kozur, 1971 , pl. 5, fig.lc) is distinctly unlike that of any other contemporaneous species.

We conclude that Solnetta (Boogardella) is a valid genus while Sohnetta (Sohnetta) is a junior synonym of Eucytherura. Boogardella is therefore raised to generic status.

Genus Speluncella Schneider (in Mandelstam et al., 1956) Type species Speluncella spinosa Schneider (in Mandelstam et al., 1956, p. 120, pl. 19, fig. 3).

Diagnosis. Egg-shaped, very rounded anteriorly, almost pointed posteriorly, smooth apart from ventro-lateral and ventral ribs (after Whatley \& Moguilevsky, 1998).

Remarks. Whatley \& Moguilevsky (1998) retained this genus in the family Spelluncellidae which they subsumed within the Limnocytheridae, Timiriasevinae. Bunza \& Kozur (1971) tentatively assigned a new species (Speluncella? karnica) to this genus but provided only two unremarkable line drawings to illustrate it (pl.1, fig. 2a,b). These drawings are similar to some species of Cytheropterinae. However, without examination of the type material or clearer illustrations it is not possible to confirm its taxonomic position. We consider the genus to be a valid taxon but not a cytherurid. Speluncella may be a senior synonym of Blomella.

Genus Telocythere Kozur, 1970b.

1973 Veghicythere Kozur: 14.

Type species. Glorianella? fischeri Kozur, 1968a (p. 860, pl. 2, fig. $12 \mathrm{a}-\mathrm{c})$.

Remarks. The type species is elongate sub-rectangular in lateral view, laterally compressed with longitudinal ribs. It was described from brackish-water deposits in association with Darwinula and Chara. The genus includes a number of species assigned by Kozur (1970a) to Lutkevichinella (Cytherissinella) which Whatley \& Moguilevsky (1998) included within the Limnocytheridae. Although the type species is somewhat similar in its external morphology to some Liassic cytherurids, there is no strong evidence to support its placement in the Cytheruridae. Based on the limited illustrations and descriptions available it is difficult to reconcile the inclusion of species such as T. tollmanni Kozur (1970b) in the same genus as the type species and there are major inconsistencies in that particular study. Pajanites, also described by Kozur (1970b), may be congeneric with Telocythere. Whatley \& Moguilevsky (1998) suggested that Pajanites may belong within the Limnocytheridae, Timiriasevinae, the brackish-water ecology of the type species supports the inclusion Telocythere within the Limnocytheridae. Telocythere may be a valid genus but is not a cytherurid.

\section{Genus Trammerella Kozur, 1973}

Type species. Timiriasevia ofentalensis Urlichs, 1972 (p. 686, pl. 2, figs 1-4).

Remarks. Although the familial assignment of this genus is uncertain, it is clearly not a cytherurid. The poor quality of the type illustrations render it impossible to establish its true familial status. The ornament resembles that of Timiriasevia, a Triassic to Early Cenozoic, fresh-brackish-water genus, but the carapace shape is distinctly different. Indeed, the carapace shape is similar to the exclusively Triassic, brackish-water genus Rhombocythere (Anderson, 1964) which Whatley \& Moguilevsky (1998) placed within the Loxoconchidae, Mandelstaminae. Until further material is made available we consider the genus valid, but not a member of the Cytheruridae.

Genus Trodocythere Kozur, 1971

Type species. Trodocythere anisica Kozur, 1971 (p. 47, pl. 2, fig. 7).

Remarks. The carapace is triangular in lateral outline with noding along the dorsal margin. There may be a lateral spine, but the type figure is unclear. There is at least one strong anteriorly produced spine (others may be missing). According to Kozur (pers. comm.), this is a marine deep water taxon. It has similarities to some deep-sea species of Eucytherura (such as Eucytherura parabatalaria Ayress et al., 1995) from the Cenozoic of the Pacific, if a little larger. Many aspects of this species suggest that it may well belong to the Bythocytheridae (straight dorsal margin, lateral spine and nodes), possibly related to genera such as Nagyella (Kozur, 1970a). This can only be resolved through studies of the adductor muscle scars; until then it is not possible to determine the validity or the familial status of this genus.

Genus Veghicythere Kozur, 1973

Type species. Lutkevichinella (Cytherissinella) multistriata Kozur, 1970a (p. 402, pl. 2, figs 6-7).

Remarks. Externally the type species is very similar to Telocythere fischeri, the type species of that genus, which we consider to belong within the Limnocytheridae. The external ornament of longitudinal ribs is also similar to that of some Liassic species of Procytherura but we do not believe this to be taxonomically significant. The genus is probably a junior synonym of Telocythere and, therefore, not a cytherurid.

Genus Wellandia Bate \& Coleman, 1975

Type species. Wellandia ornata Bate \& Coleman, 1975 (p. 32, figs $11.10-11.17)$.

Remarks. As with Rutlandella, which was erected in the same publication, we consider this genus, originally classified within the Oculocytheropterinae, to be a junior synonym of Eucytherura (see comments for Rutlandella above). 


\begin{tabular}{|c|c|c|c|}
\hline FAMILY & SUBFAMILY & VALID GENERA & SYNONYMS \\
\hline \multirow{10}{*}{ Cytheruridae } & \multirow{3}{*}{ Cytheropterinae } & Citrella Oertili, 1959 & \\
\hline & & Cytheropteron Alexander, 1933 & Infracytheropteron Kaye, 1964 \\
\hline & & Metacytheropteron Oertli, 1957 & \\
\hline & \multirow[t]{7}{*}{ Cytherurinae } & Eucytherura Müller, 1894 & $\begin{array}{l}\text { Cytheropteron (Stykella) Kozur, } 1971 \\
\text { Eocythereis Anderson, } 1964 \\
\text { Gramannicythere Grundel, } 1975 \\
\text { Gramella Kozur, 1971 } \\
\text { Grammicythere Kozur, } 1972 \\
\text { Movschovitschia Kozur, } 1971 \\
\text { Nanacythere (Domeria) Herrig, } 1969 \\
\text { Nanacythere (Goniocythere) Herrig, } 1969 \\
\text { Nanacythere (Nanacythere) Herrig, } 1969 \\
\text { Paratrachycythere Park, } 1987 \\
\text { Rutlandella Bate \& Coleman, } 1975 \\
\text { Sohnetta Kozur, 1971 } \\
\text { Wellandia Bate \& Coleman, } 1975\end{array}$ \\
\hline & & Gruendelicythere Kozur, 1971 & \\
\hline & & Judahella (Judahella) Sohn, 1968 & $\begin{array}{l}\text { Buekkella Kozur, 1985? } \\
\text { Judahella (Costahella) Kozur, } 1971 \\
\text { Mostlerella Kozur, } 1971 \\
\text { Ophthalmonodella Knüpfer \& Kozur } 1968\end{array}$ \\
\hline & & Kerocythere Kozur \& Nicklas, 1970 & $\begin{array}{l}\text { Kerocythere (Rekocythere) Kristan-Tollmann, } 1972 \\
\text { Noricythere Bolz \& Kozur, } 1971\end{array}$ \\
\hline & & Mockella Bunza \& Kozur, 1971 & $\begin{array}{l}\text { Dettermania Sohn, } 1987 \\
\text { Hasibuana Kristan-Tollmann, } 1990 \\
\text { Renicytherura Gründel, } 1981\end{array}$ \\
\hline & & Procytherura Whatley, 1970 & \\
\hline & & Boogardella Kozur, 1971 & \\
\hline \multirow{4}{*}{ Limnocytheridae } & Limnocytherinae & Simeonella Sohn, 1968 & \\
\hline & \multirow{3}{*}{ Timiriaseviinae } & Blomella Kozur, 1973 & \\
\hline & & Speluncelia Schneider, 1956 & \\
\hline & & Telocythere Kozur, 1970 & \begin{tabular}{|l} 
Pajanites Kozur, $1970 \mathrm{~b} ?$ \\
Veghicythere Kozur, 1973
\end{tabular} \\
\hline Loxoconchidae & Mandelstaminae & Trammerella Kozur, 1973 & \\
\hline \multirow{2}{*}{ Bythocytheridae? } & \multirow{2}{*}{ Subfamily uncertain } & Falloticythere Kozur et al, 1974 & \\
\hline & & Trodocythere Kozur, 1971 & \\
\hline Cytherideidae? & Subfamily uncertain & Lophodentina Apostolescu, 1959 & \\
\hline
\end{tabular}

Table 1. A taxonomic, hierarchical revision of the Early Mesozoic Cytheruridae with a list of valid genera and synonymies.

\section{SUMMARY}

A summary of our taxonomic review is given in Table 1 and the stratigraphical distribution of valid genera is presented in Fig. 1.

It is well documented that many faunal and floral lineages did not survive the mass extinction at the close of the Permian and the Ostracoda are no exception (Whatley et al., 1993). Many of the major post-Palaeozoic ostracod families were established by the mid- to Late Jurassic and we are now in a position to outline the rise of one family in particular, the Cytheruridae.

1. It is clear that certain members of this family already existed during the Permian (namely Judahella and Gruendelicythere, recorded by Kozur (1985) from northern Hungary).

2. The great similarity between some early Cytheruridae (Triassic-Early Jurassic) and Early Mesozoic Bythocytheridae (which are distinguished by the possession of five rather than four adductor muscle scars) suggests that certain elements of this polyphyletic family may have arisen from the Bythocytheridae. Indeed, this may also have been the origin of genera such as Judahella during the Late Palaeozoic. The Bythocytheridae are the oldest and longest-ranging Podocopida (Ordovician to Recent).

3. External characteristics and gross carapace morphology also support the suggestion of Gründel \& Kozur (1975) that some post-Palaeozoic Cytheracea may also have derived from the Palaeocopid Kirkbyacea (DevonianTriassic).

4. Finally, it is significant to note that many of the Triassic assemblages referred to above are recorded from shallow shelf and marginal marine (even brackish-water) environments. The opening up of new environments consequent upon the global rise of Triassic sea-level clearly played an important role in increasing marine biodiversity at this time.

There are a number of papers describing Permian ostracod assemblages which may provide evidence of links between Palaeozoic and post-Palaeozoic ostracod lineages (Kozur, 1981, 1985, 1991a, 1991 b; Gerry et al., 1987; Knüpfer, 1967). Gerry et al. (1987) included a new genus, Arqoviella, which may be ancestral to Triassic-Early Jurassic genera such as Ektyphocythere Bate, 1963.

Although this review deals essentially with the Cytheruridae, other podocopid lineages which first appeared in the Early Mesozoic also had their origins in Late Permian and Triassic times. A particular problem surrounds a number of genera recorded from Liassic sediments in NW Europe (e.g. Kinkeli- 


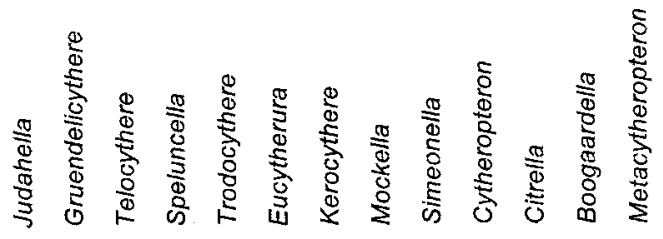

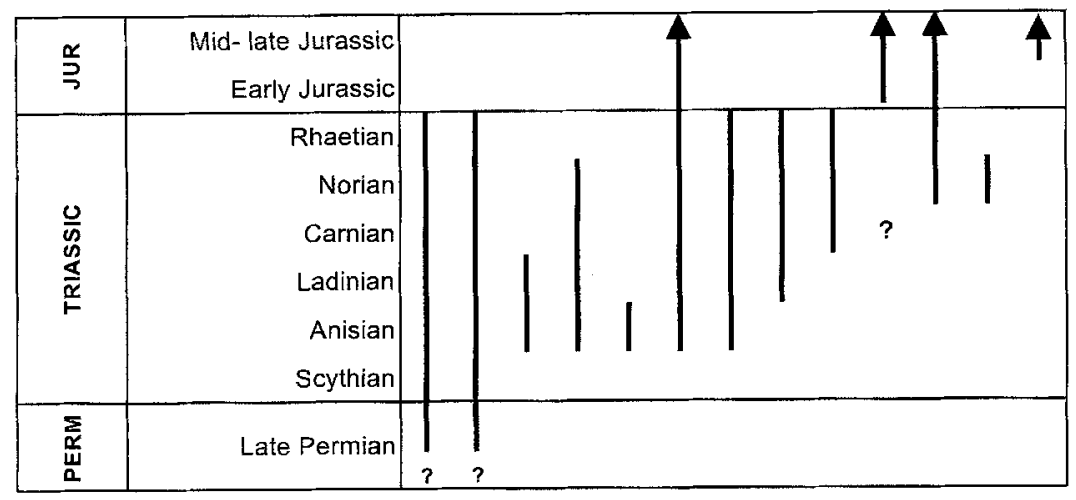

Fig. 1. Stratigraphical occurrence of valid Cytheruridae from the Early Mesozoic.

nella, Ektyphocythere, Pleurifera) which may have evolved from, or even belong to, the Cytheruridae given their merodont hingement, simple marginal pore canals and muscle scar patterns. While a study of these taxa is beyond the scope of this review, it is important to realize that such taxa may also be ancestral to other families which, with evolution, become readily separable during the Middle Jurassic. Such families include the Cytherideidae, Schulerideidae, Progonocytheridae and Protocytheridae.

The physical and biological pressures which acted upon Early Mesozoic faunas to bring about relatively rapid diversification were not confined to the early Cytheruridae; they also caused other families to become abundant and diverse.

\section{ACKNOWLEDGEMENTS}

The authors wish to acknowledge useful discussions with $\mathrm{H}$. Kozur during the compilation of this review. We also thank $\mathrm{Dr}$ Sylvie Crasquin-Soleau and an anonymous referee for their constructive comments.

\section{Manuscript received February 2000 Manuscript accepted July 2000}

\section{REFERENCES}

Alexander, C. I. 1933. Shell structure of the ostracod genus Cytheropteron and fossil species from the Cretaceous of Texas. Joumal of Paleontology, 7 (2): 181-214.

Alexander, C. I. 1936. Ostracoda of the genera Eucytherura, Cytherura and Loxoconcha from the Cretaceous of Texas. Journal of Paleontology, 10 (8): 689-694.

Anderson, F. W. 1940. Ostracoda from the Portland and Purbeck Beds at Swindon. Proceedings of the Geologists' Association, 51: 373-384.

Anderson, F. W. 1964. Rhaetic Ostracoda. Bulletin of the Geological Survey of Great Britain, 21: 133-174.

Apostolescu, V. 1959. Ostracodes du Lias du Bassin de Paris. Revue de l'Institut Français du Pétrole, 14 (6): 795-826.
Ayress, M. A., Whatley, R., Downing, S. E. \& Millson, K. J. 1995. Cainozoic and Recent deep sea Cytherurid Ostracoda from the South Western Pacific and eastern Indian Oceans, Part 1: Cytherurinac. Records of the Australian Museum, 47: 203-223.

Basha, S. H. S. 1982. Microfauna from the Triassic rocks of Jordan Revue de Micropaléontologie, 25 (1): 3-11.

Bate, R. H. 1963. Middle Jurassic Ostracoda from North Lincolnshire. Bulletin of the British Museum (Natural History) Geology, 8: 173-219.

Bate, R. H. 1972. Upper Cretaceous Ostracoda from the Carnarvon Basin, Western Australia. Special Papers in Palaeontology, 10: 1-148.

Bate, R. H. \& Coleman, B. E. 1975. Upper Lias Ostracoda from Rutland and Huntingdonshire. Bulletin of the Geological Survey of Great Britain, 55: 1-42. London.

Beutler, G. \& Gründel, J. 1963. Die Ostracoden des Unteren Keupers im Bereich des Thüringer Beckens. Freiberger Forschungshefte, C164: 3392.

Boomer, I. D. 1989. The spatial and temporal distribution of Lower Jurassic ostracods from Northwest Europe. PhD thesis, University of London.

Brady, G. S. 1867. Report on the Ostracoda dredged amongst the Hebrides. Report of the British Association for the Advancement of Science, 1866: 208-211.

Bunza, G. \& Kozur, H. 1971. Ostracoden aus den Raibler Schichten Östlich von Scholastika (Achensee, Tirol). Geologish-Paläontologische Mitteilungen Innsbruck, 1 (2): 3-13.

Crasquin-Soleau, S. \& Dépêche, F. 1992. Paleoecology of ODP Leg 122 Triassic Ostracodes (Wombat Plateau, NW Australia). Geobios, 26 (3): $331-344$.

Crasquin-Soleau, S., Dépêche, F. \& Galbrun, B. 1990. Premiers ostracodes triasiques découverts dans un forage D.S.D.P./O.D.P.: Le Leg 122 (NW de l'Australie). Comptes rendus de l'Académie des Sciences, Paris (Series II), 311: 1081-1087.

Dépêche, F. \& Crasquin-Soleau, S. 1992. Triassic marine ostracodes of the Australian Margin (Holes 759B, 760B, 761C, 764A, and 764B). Proceedings of the Ocean Drilling Program, Scientific Results, 122 453-462.

Dingle, R.V. 1984. Mid-Cretaceous Ostracoda from Southern Africa and the Falkland Plateau. Annals of the South African Museum, 93 (3): 97-211.

Fischer, W. 1962. Ostracoden der Gattungen Monoceratina Roth, 1928, Cytheropteron G. O. Sars, 1865 und andere im Lias Zeta Schwabens. Neues Jahrbuch für Geologie und Paläontologie, Abhandlungen, 114 (3): 333-345. 
Gerry, E., Honigstein, A., Derin, B. \& Flexer, A. 1987. Late Permian ostracodes of Israel. Taxonomy distribution, and paleogeographical implications. Senckenbergiana lethaea, 68 (1/4): 197-223.

Gramm, M. N. 1975. Marine Triassic Cytheracea (Ostracoda) from South Primorye (Soviet Far East). Palaeontographica, Abteilungen A, 151: $102-110$.

Gramann, F. 1962. Skulptiert Ostracoden aus den niederrheinischen Lias. Fortschritte Geologie Rheinland Westfalen, 6: 185-198.

Gründel, J. 1964. Neue Ostracoden aus der deutschen Unterkreide. I. Monatsberichte der Deutschen Akademie der Wissenschaften, Geologie und Mineralogie, Berlin, 6: 743-749.

Gründel, J. 1975. Zur entwicklung der Trachyleberididae (Ostracoda) im Jura. Zeitschfrift fiur Geologische Wissenschaften, 3: 363-374.

Gründel, J. 1981. Die Gattungen des Tribus Eucytherurini Puri, 1974 (Cytheracea s. str., Cytherocopina, Ostracoda). Zeitschrift für Geologische Wissenschaften, 9 (5): 541-552.

Gründel, J. \& Kozur, H., 1975. Systematische Gliederung und phylogenetische Beziehungen der triassischen und jurassischen $\mathrm{Cy}$ therocopina. Freiberger Forschungshefte, C139: 135-160.

Guan, S. 1985. Middle Triassic marine ostracods from Hubei. Acta Micropalaeontologica Sinica, 2(2): 169-177.

Gümbel, C.W. 1869. Über Foraminiferen, Ostrakoden und mikroskpische Thier-Überreste in den St. Cassianer und Raibler Schichten. Austria Kaiserlich-Koniglichen geologischen Reichsanstalt, Jahrbuch, 19: $175-186$.

Hanai, T., 1957. Studies on the Ostracoda from Japan, II. Subfamily Pectocytherinae, new subfamily: Journal of the Faculty of Science, University of Tokyo, 10 (3): 469-482.

Herrig, E. 1969. Ostracoden aus dem Oberen-Domerian von Grimmen Westlich Greifswald (Teil II). Geologie, 18 (9): 1072-1102.

Hornibrook, N. de B. 1952. Tertiary and Recent marine Ostracoda of New Zealand. New Zealand Geological Survey, Palaeontological Bulletin, 18: 1-82.

Ishizaki, K. \& Gunther, F.J. 1974. Ostracoda of the family Cytheruridae from the Gulf of Panama. Science Reports of the Tohoku University. Series 2 (Geology), 45 (1): 1-50.

Kaye, P. 1964. Ostracoda of the genera Eucytherura and Cytheropteron from the Speeton Clay. Geological Magazine, 101: 97-107.

Knitter, H. 1983. Biostratigraphische untersuchungen mit Ostracoden in Toarcien Suddeutschlands. Facies, 8: 213-262.

Knüpfer, J. 1967. Zur Mikrofauna aus dem unteren Teil des Zechsteins von Rügen. Freiherger Forschungshefte, C213: 73-99.

Knüpfer, J. \& Kozur, H. 1968. Eine neue Ostracodengattung aus der Trias des germanischen Binnenbeckens. Monatsberichte der Deutschen Akademie der Wissenschaften, Geologie und Mineralogie, 10 (4/5): 322 331 .

Kozur, H. 1968a. Einige seltene Ostracoden-Arten aus der germanischen Trias. Monatsherichte der Deutschen Akademie der Wissenschaften, Geologie und Mineralogie, 10 (11): 848-872.

Kozur, H. 1968b. Neue ostracoden aus dem Röt und Muschelkalk des germanischen Binnenbeckens. Monatsberichte der Deutschen Akademie der Wissenschaften, Geologie und Mineralogie, 10 (7): 498-519.

Kozur, H. 1970a. Neue Ostracoden - Arten aus dem obersten Anis des Bakonyhochlandes (Ungarn), Naturwissenschaftlich-Medizinscher Verein, Berichte, 58: 389-427.

Kozur, H. 1970b. Neue Ostracoden aus der germanischen Mittel- und Obertrias. Geologie, 19 (4): 434-454.

Kozur, H. 1971. Neue Ostrakodenarten aus der Tethyalen Trias. Geologisch-Paläontologische Mitteilungen Innsbruck, 1 (2): 14-76.

Kozur, H. 19\%2a. Die Bedeutung triassischer Ostracoden für stratigraphische und paläoökologische Untersuchungen. Mitteilungen $\mathrm{Ge}$ sellschaft Geolgisches Bergbaustudieren, 21: 623-660.

Kozur, H. 1972b. Einige Bemerkungen zur Systematik der Ostracoden und Beschreibung neuer Platycopida aus der Trias Ungarns und der Slowakei. Geologisch-Patäontologische Mitteihngen Innsbruck, 2 (10): $1-27$.

Kozur, H. 1973. Beiträge zur Ostracodenfauna der Trias. GeologischPaläontologische Mitteilungen Innsbruck, 3 (5): 1-41.

Kozur, H. 1981. Einige neue Ostracoden-arten aus dem Oberperm des Bükk-Gebirges (Nordungarn). Proceedings of the Belgrade Geoinstitute, 15: 199-206.

Kozur, H. 1985. Neue Ostracoden-arten aus dem Oberen Mittelkarbon
Höheres Moskovian), Mittel- und Oberperm des Bükk-Gebirges (N Ungarn). Geologisch-Paläontologische Mitteilungen Innsbruck, 2: 1145

Kozur, H. 1991a. Permian deep-water ostracods from Sicily (Italy). Part 1: Taxonomy. Geologisch-Paläontologische Mitteilungen Innsbruck, 3: $1-24$.

Kozur, H. 1991b. Permian deep-water ostracods from Sicily (Italy). Part 2: Biofacial evaluation and remarks to the Silurian to Triassic palaeopsychrospheric ostracods. Geologisch-Paläontologische Mitteilungen Innsbruck, 3: 25-38.

Kozur, H. Kampschuur, W., Mulder-Blanken, C. W. H. \& Simon, O. J. 1974. Contribution to the Triassic ostracode faunas of the Betic Zone (southern Spain). Scripta Geologica, 23: 1-56.

Kozur, H. \& Nicklas, L. 1970. Ostrakoden aus dem Plattenkalk-Niveau des Hauptdolomites (Rhätikon). Festband der Geologishes Institut 300 Jahr-Feier Universität Innsbruck, 309-320.

Kristan-Tollmann, E. 1972. Die obertriadischen Arten der OstracodenGattung Kerocythere Kozur \& Nicklas, 1970, und ihr stratigraphischer Wert. Erdoel-Erdgas-Zeitschrift, 88: 43-49.

Kristan-Tollmann, E. 1982. Bemerkungen zur triadischen OstracodenGattung Mostlerella. Neues Jahrbuch für Geologie und Paläontologie, Monatshefte, 9: 560-572.

Kristan-Tollmann, E. 1983. Ostracoden aus dem Oberanis von Leipado bei Guiyang in Südchina. Schriftenreihe der Erdwissenscaften Komissionen Österreichische Akademie der Wissenschaften, 5: 121-176.

Kristan-Tollmann, E. 1986. Beobachtungen zur Trias am Südostende der Tethys-Papua/Neuguinea, Australien, Newseeland. Neues Jahrbuch für Geologie und Paläontologie. Monatshefte, 4: 201-222.

Kristan-Tollmann, E. 1988. Unexpected microfaunal communities within the Triassic Tethys. In Audley-Charles, M. \& Hallam, A (Eds), Gondwana and Tethys, 213-223. Geological Society, London, Special Publication, 37.

Kristan-Tollmann, E. 1989. Untersuchungen zum Schloßbau triadischer Cytheracea (Ostracoda). Courier der Forschungsinstitut Senckenberg, 113: 49-60.

Kristan-Tollmann, E. \& Gramann, F. 1992. Paleontological evidence for the Triassic age of rocks dredged from the Northern Exmouth Plateau (Tethyan foraminifers, Echinoderms, and Ostracodes). In von Rad, U., Haq. B. U. ef al. (Eds), Proceedings of the Ocean Drilling Project, Scientific Results, 122: 463-474. College Station, TX

Kristan-Tollmann, E., Haas, J. \& Kovacs, S. 1991a. Karnische Ostracoden und Conodonten der Bohrung Zsámbék-14 im Transdanubischen Mittelgebirge (Ungarn). Jubiläumsschrift 20 Jahre Geologische Zusammenarbeit Osterreich Ungarn, 1: 193-219.

Kristan-Tollmann, E. \& Hasibuan, F. 1990. Ostracoden aus der Obertrias von Misol (Indonesien). Mitteilungen der Österreicher Geologisches Gesellschaft, 82: (for 1989) 173-181.

Kristan-Tollmann, E., Lobitzer, H., Solti, et al. 1991b. Mikropaläontologie und geochime der Kössner Schichten des KarbonatplattformBecken-Komplexes Kammerköhralm - Steinplatte (Tirol/Salzburg). Jubiläumsschrift 20 Jahre Geologische Zusammenarbeit Österreich Ungarn, 1: 155-191.

Lord, A. R., Malz, H. \& Apthorpe, M. 1993. Lower Jurassic Ostracoda from off Western Australia. In McKenzie, K. G. \& Jones, P. J. (Eds), Ostracoda in the Eurth and Life Sciences, 109-121, A. A. Balkema.

Maddocks, R. F. \& Steineck, P. L. 1987. Ostracoda from experimental wood-island habitats in the deep-sea. Micropaleontology, 33 (4): $318-$ 355.

Mandelstam, M. I., Schneider, G. F., Kuznetsova, Z. V. \& Ljubimova, P. S. 1956. $m$ : Kiparisova, L. D. Markovski, B. P. \& Radchenko, G. P. (Eds), Ostracoda, new families and genera. Papers in Paleontology. VSEGEI (New Series), 12: 87-144. Moscow.

Michelsen, O. 1975. Lower Jurassic biostratigraphy and ostracods of the Danish Embayment. Dammarks Geologiske Undersagelse, II Raeke, 104: $1-287$.

Müller, G. W. 1894. Des Ostracoden des Golfes von Neapel und der angrenzenden Meeresabschnitte. Fauna und Flora des Golfes von Neapel. Monograph, 21: 1-434.

Neale, J. W. 1975. The ostracod fauna from the Santonian chalk (Upper Cretaceous) of Gingin, Western Australia. Special Papers in Palaeontology, 16: $1-81$.

Oertli, H. J. 1957. Ostracodes du Jurassique supérieur du bassin de Paris 
(sondage Vernon 1). Revue de l'Institut Français du Pétrole. 12 (6): 664. Oertli, H. J. 1959. Les Ostracodes du Bathonien du Boulonnais; I - 'Les Micro-Ostracodes". Revue de Micropaléontologie. 2 (3): 117. Paris.

Orlov, Y. I. 1960. (Ed.) Osnovy Paleontologii. Arthropoda. Treatise on Paleontology, 1-515.

Park, S. M. 1987. The ostracod zones and subzones of the Lower Jurassic in the Southern North Sea Basin. Journal of the Paleontological Society of Korea, 3: 44-70.

Pokorny, V. 1973. The Ostracoda of the Klentnice Formation (Tithonian?) Czechoslovakia. Rozpravy, Ustredniho Ustavu Geologickeho, Svazek, 40: 1-105.

Schleifer, A. G. 1966. Ostracoda of the Lower Triassic Baskunchak Series from the Pricaspian Depression and their stratigraphic importance. In Gubkina, I. M. (Ed.), Geology of the Russian Platform, 112-139. Trudy, Moscow.

Sohn, I. G. 1968. Triassic ostracodes from Makhtesh Ramon, Israel. Israel Geological Survey, Bulletin, 44: 1-7I.

Sohn, I. G. 1970. Early Triassic marine Ostracodes from the Salt Range and Surghar Range, West Pakistan. In Kummel, B. \& Teichert, C. (Eds), Stratigraphic Boundary Problems: Permian and Triassic of West Pakistan, 193-206. University of Kansas Special Publication 4.

Sohn, I. G. 1987. Middle and Upper Triassic marine Ostracoda from the Shublik Formation, Northeastern Alaska. Bulletin of the United States Geological Survey, 1664 (C): 1-24.

Triebel, E. \& Klingler, W. 1959. Neue Ostracoden-Gattungen aus dem deutschen Lias. Geologische Jahrbuch, 76: 335-372.

Urlichs, M. 1972. Ostracoden aus den Kössener Schichten und ihre Abhängigkeit von der Ökologie. Mitteilungen Gesellschaft Geolgisches Bergbaustudieren, 21: 661-710.
Warthin, A. S. 1930. Micropaleontology of the Wetumka, Wewoka and Holdenville Formations. Oklahoma Geological Survey, Bulletin, 53: 195.

Weaver, P. P. E. 1982, Ostracoda from the British Lower Chalk and Plenus Marls. Palaeontographical Society Monograph, 135: 1-127.

Whatley, R. C. 1970. Scottish Callovian and Oxfordian Ostracoda. British Museum (Natural History) Bulletin, Geology, 19 (6): 299-358.

Whatley, R. C. 1988. Patterns and rates of Evolution among Mesozoic Ostracoda. In Hanai, T., Ikeya, N. \& Ishizaki, K. (Eds), Evolutionary Biology of Ostracoda its fundamentals and applications, Volume 11, 1021-1040. Kodansha Ltd, Tokyo.

Whatley, R. C. \& Ballent, S. 1996. A review of the ostracod genus Progonocythere and its close allies. Palaeontology, 39 (4): 919939.

Whatley, R. C \& Moguilevsky A. 1998. The origin and early evolution of the Limnocytheridae (Crustacea, Ostracoda). In Crasquin-Soleau, S., Braccini, E. \& Lethiers, F. (Eds), What about Ostracoda! Bulletin du Centre de Recherches Elf Exploration Production, Mémoires., 20: 271 285.

Whatley, R. C., Siveter, D. J. \& Boomer, I. D. 1993. Arthropoda (Crustacea: Ostracoda). In Benton, M. J. (Ed.), The Fossil Record 2, 343-356. Chapman \& Hall, London.

Whatley, R. C. \& Stephens, J. M. 1976. The Mesozoic explosion of the Cytheracea. Abhandlungen und Verhandlungen des Naturwissenschaftlichen Vereins in Hamburg (Neue Folge), 18/19 (Suppl.): 63-76.

Zheng, S-Y. 1988. Marine Ostracods from the Middle Triassic near Nanjing. Acta Micropalaeontologica Sinica, 5 (2): 195-198. [In Chinesel.

Zhong, X.-C. 1964. Upper Triassic and Middle Jurassic ostracodes from the Ordos Basin. Acta Palaeontologica Sinica, 12 (3): 426-474 